\title{
Audible Device Noise
}

National Cancer Institute

\section{Source}

National Cancer Institute. Audible Device Noise. NCI Thesaurus. Code C99179.

An unintended or unpleasant sound that emanates from a device. 